\title{
UPAYA PENCEGAHAN HIPERTENSI PADA IBU BALITA DI DESA KALITIDU KABUPATEN BOJONEGORO
}

\section{HYPERTENSION PREVENTION EFFORTS OF MOTHER AT KALITIDU DISTRICT BOJONEGORO}

\author{
Rifki Oksantika \\ Program Studi Kesehatan Masyarakat, Fakultas Kesehatan Masyarakat, Universitas \\ Airlangga \\ email: rifki.oksantika-2016@fkm.unair.ac.id
}

\begin{abstract}
Hypertension during pregnancy is one of pregnancy problem that often causes complication. Complication in pregnancy has high risk of prenatal and neonatal mortality. Based on the results of questionnaire, even though they have good knowledge, the behavior carried out by the community is still unhealthy. Through hypertension prevention activities to the toddler's mother can increase knowledge and motivate them to improve their health status. Mother needs to improve their health status, especially those who are prepare to get pregnant. Prevention efforts are carried out by three activities namely Kupandu Makanmu, Pembina Selasih, and Tirakato. The method used is a direct counselling for toddler's mother in Kalitidu District Bojonegoro. Through this activity, there was an increase of mother's knowledge about hypertension by $80 \%$, and 23 out of 36 families approved Tirakato action.
\end{abstract}

Keywords: Hypertension, Mother, Prevention

abstrak

Hipertensi pada masa kehamilan merupakan salah satu masalah kehamilan yang seringkali menyebabkan komplikasi. Komplikasi pada kehamilan memiliki risiko tinggi mengalami kematian prenatal dan neonatal. Berdasarkan hasil kuesioner, meskipun memiliki pengetahuan yang baik, perilaku yang dilakukan masyarakat masih tidak sehat. Melalui kegiatan penanggulangan hipertensi pada ibu balita dapat meningkatkan pengetahuan dan memotivasi ibu balita untuk meningkatkan status kesehatannya. Peningkatan status kesehatan penting dilakukan ibu, terutama bagi ibu yang sedang menyiapkan diri untuk hamil. Upaya penanggulangan dilakukan dengan melaksanakan tiga rangkaian kegiatan yakni Kupandu Makanmu, Pembina Selasih dan Tirakato. Metode yang digunakan adalah penyuluhan langsung dengan sasaran ibu balita di Desa Kalitidu, Kabupaten Bojonegoro. Melalui kegiatan tersebut, terdapat peningkatan pengetahuan ibu balita mengenai hipertensi sebesar $80 \%$ serta 23 dari 36 keluarga menyetujui aksi Tirakato.

Kata kunci: Hipertensi, Ibu, Pencegahan

\section{PENDAHULUAN}

Hipertensi pada kehamilan didefinisikan sebagai kenaikan tekanan darah $\geq 140 / 90$ mmHg yang terjadi setelah usia kehamilan 20 minggu pada wanita yang sebelumnya normotensif, atau kenaikan tekanan sistolik $30 \mathrm{mmHg}$ dan diastolik $15 \mathrm{mmHg}$ diatas nilai normal (Junaidi, 2010). Hipertensi pada kehamilan menjadi salah satu masalah 
pada kehamilan yang dapat menyebabkan komplikasi pada $10 \%$ kehamilan di dunia (Roberts et al., 2013). Di Amerika Serikat, kehamilan dengan hipertensi diperkirakan mencapai $6-10 \%$ dimana terdapat 4 juta wanita hamil dengan 240.000 diantaranya mengalami hipertensi.

Hipertensi pada kehamilan dapat dikelompokkan menjadi empat, yakni hipertensi kronik, preeklampsia, preeklampsia pada hipertensi kronik, dan hipertensi gestasional. Diantaranya, preeklampsia adalah kejadian sering terjadi pada kehamilan (Hinkosa et al., 2020) Diperkirakan kejadian preeklampsi meningkat sebanyak 25\% dalam dua dekade terakhir (Roberts et al., 2013). Kehamilan dengan preeklampsia memiliki kontribusi besar dalam mordibitas dan mortalitas neonatal (Krishnachetty, 2014).

Hipertensi pada wanita hamil memiliki potensi menimbulkan beberapa komplikasi dan dapat menyebabkan gagal ginjal akut, pendarahan saat dan sesudah persalinan, HELLP (Hemolysis Elevated Liver Enzymes and Low Platelet Count) dan kejang (Khosravi et al., 2014). Akibat lain yang timbul dari kehamilan dengan hipertensi yakni bayi prematur, gangguan pertumbuhan janin, kematian janin, bayi lahir dengan berat kurang dari $10 \%$, serta beresiko mengalami kematian perinatal dan neonatal yang lebih tinggi dibandingkan wanita hamil yang tidak mengalami hipertensi (Roberts et al., 2013).

Terdapat beberapa kondisi yang dapat mempengaruhi kejadian hipertensi pada kehamilan. Menurut Imaroh et al (2018), faktor yang dapat menyebabkan hipertensi diantaranya usia yang terlalu muda atau terlalu tua, riwayat pendidikan, pekerjaan, primigravida, memiliki keluarga dengan riwayat hipertensi, riwayat abortus, serta konsumsi natrium berlebihan selama hamil. Faktor lain yang mempengaruhi hipertensi pada kehamilan yakni kehamilan pertama kali, kehamilan kembar, memiliki riwayat diabetes, serta tinggal di wilayah pedesaaan (Hinkosa et al., 2020).

Perilaku masyarakat terhadap hipertensi pada kehamilan masih tergolong tidak sehat. Berdasarkan hasil kuesioner yang telah disebarkan pada 110 ibu balita di Desa Kalitidu, Kecamatan Kalitidu, Kabupaten Bojonegoro diperoleh informasi bahwa meski memiliki pengetahuan dan sikap yang baik terkait hipertensi, namun hal tersebut tidak sesuai dengan perilaku ibu. Hal ini didukung dengan hasil kuesioner yang menyatakan 70,9\% responden masih berperilaku tidak sehat. Perilaku tidak sehat yang sering dilakukan yakni masih adanya anggota keluarga satu rumah yang merokok, kurangnya variasi makanan, dan kurangnya aktivitas fisik. Dalam hal ini, pemberdayaan dengan memotivasi masyarakat dalam memperbaiki perilaku menjadi lebih sehat perlu dilakukan sehingga dapat terwujud masa kehamilan yang sehat.

\section{METODE PENGABDIAN MASYARAKAT}

Kegiatan pengabdian masyarakat dilaksanakan di Desa Kalitidu, Kecamatan Kalitidu, Kabupaten Bojonegoro. Metode pelaksanaan kegiatan pengabdian masyarakat dirancang sebagai berikut: 1). Menganalisis situasi masyarakat; 2). Mengidentifikasi masalah kesehatan yang dialami masyarakat; 3). Menentukan prioritas masalah; 4). 
Menyusun rencana intervensi; dan 5). Melaksanakan kegiatan pemberdayaan masyarakat

Analisis situasi masyarakat. Desa Kalitidu merupakan pusat dari Kecamatan Kalitidu dengan luas wilayah sebesar $182.365 \mathrm{~km}^{2}$ yang terbagi menjadi 2 dusun yakni Dusun Krajan dan Dusun Gangsalan. Berdasarkan Profil Puskesmas Kalitidu tahun 2018, jumlah penduduk di Desa Kalitidu adalah 3.398 jiwa yang terdiri dari 1.774 laki-laki dan 1.624 perempuan. Mata pencaharian penduduk sebagian besar adalah buruh tani dengan aktifitas utama bertanam padi, terong, dan kangkung (Profil Desa Kalitidu 2018).

Identifikasi masalah. Identifikasi masalah dilakukan melalui pendekatan kepada stakeholder terkait yakni kepala desa, petugas puskesmas, bidan desa, dan kader posyandu. Berdasarkan data primer yang didapat melalui observasi, indepth interview, dan kuesioner dasar diperoleh lima besar masalah kesehatan yakni hipertensi, TB Paru, pneumonia pada balita, diare, dan gizi kurang balita.

Menentukan prioritas masalah. Prioritas masalah ditentukan menggunakan metode MCUA berdasarkan perhitungan hasil pembobotan berdasarkan kriteria yang disepakati oleh kelompok. Kriteria yang digunakan dalam menentukan prioritas adalah kepentingan masalah, kegawatan masalah, sumber daya, dan kemudahan dalam mengatasi masalah. Berdasarkan hasil perhitungan, prioritas masalah yang ada di Desa Kalitidu adalah hipertensi pada ibu balita

Mengidentifikasi akar masalah. Identifikasi akar masalah penyebab hipertensi pada ibu dilakukan menggunakan fishbone. Berdasarkan hasil fishbone, penyebab hipertensi pada ibu diantaranya rendahnya variasi bahan makanan, paparan asap rokok anggota keluarga, kurangnya jumlah tenaga kesehatan, dan kurangnya informasi skrining hipertensi.

Menyusun rencana intervensi. Rencana Intervensi disusun berdasarkan prioritas solusi yang didapat melalui perhitungan MEER. Hasilnya, terdapat 3 rencana kegiatan yang akan dilakukan yakni Buku Panduan Pola Makan Sehat (Kupandu Makanmu), Pembagian Bibit Seledri atasi Hipertensi (Pembina Selasih) dan Matikan Rokok dalam Pot (Tirakato).

Pelaksanaan intervensi. Kegiatan intervensi dilaksanakan pada tanggal 22-24 Juli 2019. Pelaksana kegiatan terdiri dari mahasiswa PKL Fakultas Kesehatan Masyarakat Universitas Airlangga didampingi Bidan Desa Kalitidu, kader posyandu, ibu balita, dan tenaga kesehatan dari Puskesmas Kalitidu. Sasaran kegiatan ibu-ibu yang memiliki balita di Desa Kalitidu, Kecamatan Kalitidu, Kabupaten Bojonegoro. 


\section{HASIL DAN PEMBAHASAN}

Hipertensi pada kehamilan merupakan masalah kesehatan yang terjadi disebabkan oleh peningkatan tekanan darah $\geq 140 / 90 \mathrm{mmHg}$ pada wanita hamil selama masa kehamilan. Pada umumnya, hipertensi pada kehamilan dapat dikelompokkan menjadi 4 antara lain: 1.) Hipertensi kronis: hipertensi yang terjadi sebelum kehamilan atau 20 minggu kehamilan pertama; 2.) Preeklampsia: hipertensi akibat keracunan kehamilan yang dapat disertai edema dan proteinuria; 3.) Preeklampsia pada hipertensi kronik: hipertensi gabungan preeklampsia dengan hipertensi kronik; 4.) Hipertensi gestasional: hipertensi yang terjadi setelah 20 minggu kehamilan tanpa disertai proteinuria.

Perilaku adalah respon seseorang terhadap suatu stimulus yang berasal dari dirinya. Perilaku seseorang terpengaruh oleh lingkungan dan dalam dirinya. Terdapat tiga aspek yang mempengaruhi perilaku seseorang yakni aspek pengetahuan, sikap dan perbuatan. Dalam hal ini, perubahan perilaku dimulai dari perkembangan pengetahuan yang kemudian diikuti perkembangan bersikap, sehingga tindakan hidup sehat tercapai.

Berdasarkan hasil kuesioner yang telah disebarkan terhadap 110 ibu balita di Desa Kalitidu, Kecamatan Kalitidu, Kabupaten Bojonegoro dapat diketahui bahwa pengetahuan dan sikap yang dimiliki ibu terkait hipertensi sudah cukup baik. Namun, hal tersebut tidak berbanding lurus dengan tindakan kesehariannya. Sebanyak 70,9\% responden masih berperilaku tidak sehat. Dengan demikian, perlunya meningkatkan motivasi masyarakat untuk memicu perbaikan tindakan masyarakat dalam mencegah hipertensi terutama pada rencana kehamilan ke depannya.

Kegiatan penanggulangan hipertensi pada ibu balita dilakukan dalam tiga kegiatan yang bertujuan meningkatkan perilaku hidup sehat masyarakat dalam mencegah hipertensi pada ibu terutama saat hamil. Kegiatan dilakukan dengan melibatkan ibu balita di Desa Kalitidu dan stakeholder terkait yakni bidan desa, kader posyandu, dan petugas Puskesmas Kalitidu. Rangkaian kegiatan pengabdian masyarakat meliputi tiga kegiatan yakni pembagian buku panduan pola makan sehat, pembagian bibit seledri, dan sosialisasi matikan rokok sebelum masuk rumah menggunakan pot yang diletakkan diluar rumah.

\section{Kegiatan Pembagian Buku Panduan Pola Makan Sehat (Kupandu Makanmu)}

Pola makan dapat mempengaruhi status gizi seseorang. Hal ini dikarenakan kuantitas dan kualitas makanan yang dikonsumsi dapat mempengaruhi status gizi sehingga berpengaruh pada derajat kesehatan seseorang. Menjaga pola makan dilakukan oleh setiap orang, termasuk wanita yang sedang menyiapkan diri untuk hamil. Pola makan yang sehat dapat menjadikan tubuh selalu sehat, sehingga diharapkan bayi yang akan di kandung pun sehat.

Berdasarkan penelitian oleh Taslim, et al (2016), dapat diketahui bahwa pola makan memiliki hubungan dengan kejadian hipertensi pada ibu hamil. Ditemukan $27(77,1 \%)$ responden tidak menerapkan pola hidup sehat dimana responden lebih banyak mengkonsumsi daging, makanan berlemak, gorengan, dan makanan yang mengandung 
garam lebih dari tiga kali seminggu. Konsumsi garam terlalu sering dapat berdampak pada meningkatnya fungsi jantung untuk memompa darah. Hal ini terjadi akibat adanya peningkatan kadar garam dan air dalam tubuh yang harus disaring oleh ginjal dikarenakan masuk dan keluar darah haruslah seimbang.

Pola makan tidak sehat dapat dipengaruhi oleh kurangnya pengetahuan masyarakat dalam mengkombinasikan bahan pangan. Hal tersebut sejalan dengan penelitian yang dilakukan oleh Goni, et al (2013) yakni pengetahuan dapat mempengaruhi status gizi selama kehamilan. Pengetahuan merupakan hal utama dalam membentuk tindakan seseorang. Tingkat pengetahuan yang rendah dapat menyebabkan ibu tidak memahami cara pemenuhan nutrisi yang dibutuhkan dengan mengkombinasi bahan pangan yang mudah untuk didapatkan.

Kegiatan pembagian Buku Panduan Pola Makan Sehat (Kupandu Makanmu) untuk ibu hipertensi bertujuan untuk meningkatkan pengetahuan masyarakat mengenai menu makanan sehat yang dapat dikonsumsi untuk membantu mencegah hipertensi. Booklet atau buku panduan yang diberikan terdiri informasi terkait hipertensi, panduan mengenai pola makan yang baik untuk penderita hipertensi, contoh menu makanan sehari-hari, metode memasak yang benar dan baik, serta upaya yang dapat dilakukan untuk mencegah hipertensi.

Kegiatan Kupandu Makanmu dilaksanakan pada tanggal 24 Juli 2019 di RA/KB Al Maul Ihsan Desa Kalitidu. Kegiatan tersebut dilakukan dengan cara membagikan booklet atau buku panduan dan sosialisasi secara langsung. Sosialisasi dilakukan secara langsung pada kegiatan kelas ibu balita. Sasaran kegiatan Kupandu Makanmu adalah para ibu yang memiliki balita terutama ibu dengan risiko hipertensi. Materi sosialisasi yang diberikan yakni terkait hipertensi diantaranya pengertian, gejala, bahaya, upaya pencegahan, serta pengenalan sumber makanan yang dianjurkan dan tidak bagi penderita hipertensi.

Selama kegiatan kupandu makanmu berlangsung, peserta sangat antusias mengikuti rangkaian acara. Hal ini ditunjukkan dengan beragam pertanyaan yang disampaikan oleh peserta terurama terkait pengenalan sumber makanan dan menu makan sehari-hari untuk penderita hipertensi. Melalui kegiatan tersebut, $43 \%$ dari 28 ibu yang hadir mampu menjawab post test dengan nilai baik dan mendapatkan nilai di atas 80 . Hal ini menunjukkan adanya peningkatan pengetahuan sebesar $80,7 \%$ berdasarkan perbandingan nilai pre-test dan post-test peserta. 


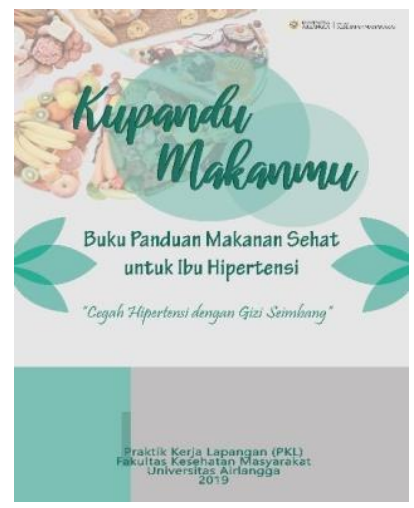

Gambar 1. Cover Booklet Kupandu Makanmu

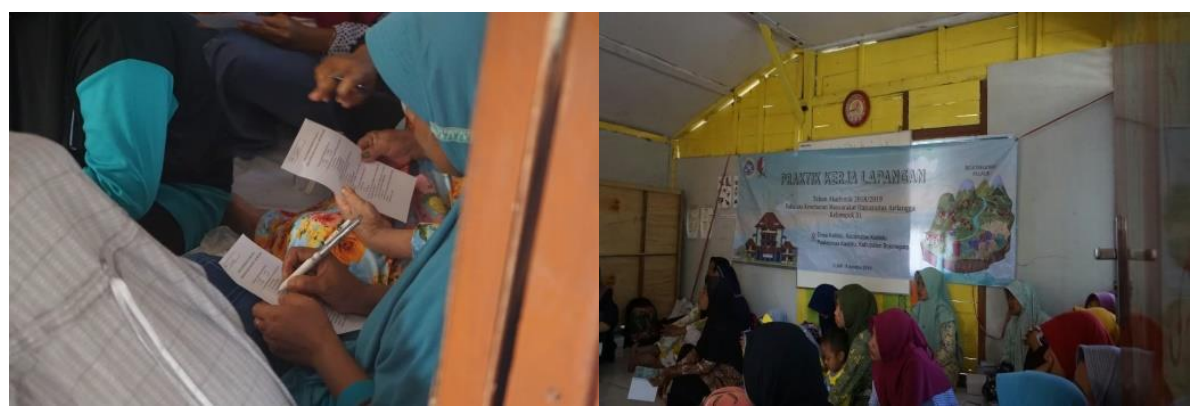

Gambar 2. Sosialisasi terkait hipertensi

\section{Kegiatan Pembagian Bibit Seledri (Pembina Selasih)}

Penanggulangan hipertensi bertujuan untuk mengontrol tekanan darah dan mencegah komplikasi. Hal tersebut dapat dilakukan melalui dua acara yakni dengan menggunakan obat dan modifikasi asupan makanan (Buheli \& Usman, 2019). Selain itu, hipertensi dapat ditanggulangi dengan melakukan pengobatan herbal. Pengobatan herbal merupakan pengobatan yang dilakukan dengan menggunakan bahan alami seperti tanaman obat yang sudah teruji secara klinis maupun preklinis (Mursito, 2002).

Seledri (Apium graveolens) merupakan tanaman yang bagian batang dan daunnya seringkali digunakan untuk membantu menurunkan tekanan darah bagi penderita hipertensi. Daun seledri mengandung apigenin yang mampu berfungsi sebagai beta blocker untuk memperlambat detak jantung dan menurunkan kekuatan kontraksi jantung sehingga tekanan darah dapat berkurang. Selain itu, daun seledri juga mengandung mannitol dan apiin yang bersifat diuretic yang dapat membantu ginjal untuk mengeluarkan cairan dan garam yang berlebih di dalam tubuh sehingga tekanan darah dapat berkurang (John, 2005).

Kegitan pembagian bibit seledri (Pembina Selasih) bertujuan untuk meningkatkan pengetahuan ibu mengenai variasi olahan dan cara mengolah seledri sebagai alternatif menjaga tekanan darah. Kegiatan pembagian bibit seledri menjadi satu rangkaian kegiatan yang dilaksanakan setelah pembagian buku paduan pola makan sehat. Rincian 
kegiatannya adalah pemberian penyuluhan mengenai manfaat menanam seledri, demo pengolahan seledri, dan pembagian bibit seledri.

Penyuluhan dilakukan secara face to face dengan menggunakan media power point . Materi yang diberikan yakni manfaat seledri dan demo cara membuat jus seledri. Demo cara membuat jus seledri dilakukan dengan menunjukkan cara membuat jus seledri dan menunjukkan jus yang telah dibuat sebelumnya untuk dicoba. Jus seledri dibuat dengan mencampurkan belimbing dan seledri yang sudah dicuci serta sedikit gula atau madu sesuai dengan selera. Belimbing manis mengandung kalium da natrium yang baik bagi penderita hipertensi (Astawan, 2009). Selain itu, dengan menambahkan belimbing pada jus seledri bau menyengat yang ada pada seledri dapat tersamarkan.

Pelaksanaan kegiatan Pembina selasih dilangsungkan dengan baik sesuai dengan perencanaan kegiatan. Peserta kegiatan sangat antusias dengan demo cara membuat jus seledri. Hal ini dibuktikan dengan banyaknya peserta yang mencoba jus seledri yang telah dibuat dan banyaknya feedback berupa pertanyaan yang diberikan oleh peserta. Berdasarkan testimoni peserta, jus seledri yang telah dibuat memiliki rasa yang enak dan mudah, sehingga membuat mereka ingin membuatnya sendiri di rumah.

Di akhir kegiatan, setiap peserta yang mengikuti kegiatan mendapatkan satu bibit seledri. Pemberian bibit seledri dilakukan dalam rangka meningkatkan apotik hidup tiap keluarga untuk menjaga kesehatan melalui pengobatan herbal untuk mengatasi hipertensi. Selain itu, tanaman seledri tidak memerlukan perawatan khusus dan mudah untuk ditanam dalam pot. Melalui kegiatan tersebut, $43 \%$ dari 28 ibu yang hadir mampu menjawab post test dengan nilai baik dan mendapatkan nilai di atas 80 . Hal ini menunjukkan adanya peningkatan pengetahuan sebesar $80,7 \%$ berdasarkan perbandingan nilai pre-test dan post-test peserta.
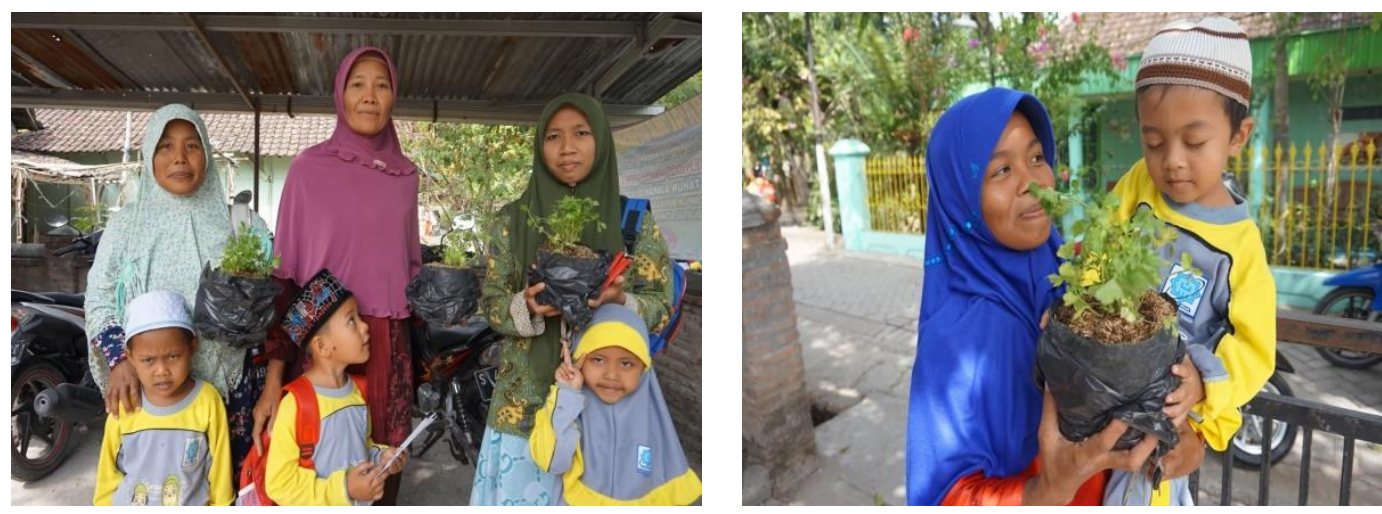

Gambar 3. Pembagian Bibit Tanaman Seledri pada Ibu Balita

\section{Sosialisasi Matikan Rokok dalam Pot (Tirakato)}

Paparan asap rokok merupakan salah satu faktor yang dapat mempengaruhi kejadian hipertensi pada kehamilan. Wanita hamil yang terpapar asap rokok memiliki risiko 2,43 kali lebih besar menderita preeklampsia dibandingkan wanita hamil yang tidak terpapar. 
Hal ini yang dilakukan oleh Luo (2014) juga menyatakan risiko preeklampsia pada ibu hamil yang terpapar rokok (perokok pasif) meningkat 6 kali.

Ibu hamil yang menjadi perokok pasif dapat berisiko mengalami kenaikan denyut jantung yang berdampak pada peningkatan tekanan darah. Hal ini disebabkan oleh karbon dioksida $\left(\mathrm{CO}_{2}\right)$ yang dihirup dapat menyebabkan pasukan oksigen dalam jaringan tubuh berkurang. Jaringan tubuh yang kekurangan pasokan oksigen berusaha meningkatkan pasokan melalui kompensasi pembuluh darah dengan jalan spasme yang menyebabkan peningkatan tekanan darah. Selain itu, paparan asap rokok dapat berpengaruh pada perubahan morfologi plasenta yang menyebabkan terganggunya fungsi endothel. Terganggunya fungsi endothel mengakibatkan peningkatan permeabilitas vaskuler sehingga dapat menyebabkan edema dan proteinuria.

Berdasarkan hasil kuesioner yang telah disebarkan sebelumnya, dapat diketahui bahwa sebanyak 55,13\% keluarga terdapat perokok aktif yang didominasi jenis kelamin laki-laki. Hal ini menunjukkan bahwa perilaku merokok dalam rumah masih sering dilakukan oleh anggota keluarga serumah. Apabila terdapat ibu hamil dalam rumah tersebut tentunya dapat berdampak buruk bagi kehamilannya. Maka dari itu, perlu adanya edukasi terkait pentingnya tidak merokok dalam rumah.terutama bagi anggota keluarga berjenis kelamin laki-laki.

Kegiatan mematikan putung rokok dalam rokok (Tirakato) bertujuan untuk memberikan wawasan kepada perokok terkait dengan bahaya asap rokok. Sasaran dari kegiatan ini adalah anggota keluarga merokok yang memiliki balita usia 0 hingga 59 bulan di Desa Kalitidu. Kegiatan dilaksanakan pada tanggal 19 Juli 2019 dengan dua rencana kegiatan yakni penyuluhan mengenai bahaya rokok dan membagikan pot.

Penyuluhan mengenai bahaya rokok dilakukan face to face dengan cara datang langsung ke setiap rumah sasaran. Untuk mempermudah proses pembelajaran, penyuluh menggunakan media yakni poster. Materi penyuluhan yang diberikan pada sasaran yakni kandungan rokok dan bahaya merokok di dalam rumah. Selain memberikan penjelasan, penyuluh juga memberikan pot pada peserta. Pemberian pot dimaksudkan sebagai media mematikan rokok sebelum masuk ke dalam rumah yang diletakkan di depan rumah peserta.

Penyuluhan yang dilakukan dengan face to face baik satu ataupun dua arah memiliki keuntungan bagi penyuluh dikarenakan dapat langsung melihat ekspresi dan respon yang diberikan peserta selama proses kegiatan berlangsung. Selama kegiatan berlangsung, sasaran menunjukkan ekspresi sangat antusias. Antusias peserta dapat ditunjukkan dari feedback peserta berupa pertanyaan yang diajukan kepada penyuluh. Melalui kegiatan ini 23 dari 36 anggota keluarga merokok yang mendapatkan pot menyetujui aksi Tirakato. 


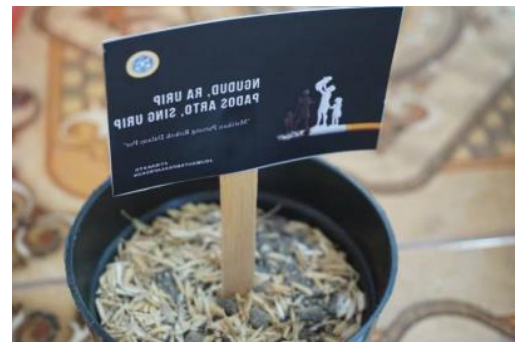

Gambar 4. Pot sebagai media mematikan rokok

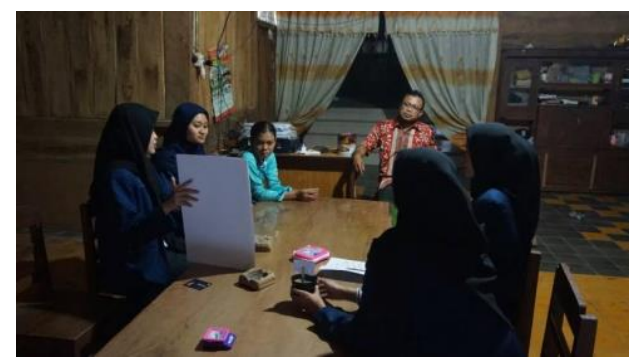

Gambar 5. Pemberian materi penyuluhan kepada sasaran

\section{PENUTUP}

\section{Simpulan}

Kegiatan yang diselenggarakan untuk menanggulangi hipertensi pada ibu balita memberikan dampak positif berupa peningkatan pengetahuan dan antusiasme peserta. Antusiasme peserta dapat terlihat keaktifan dan feedback peserta selama mengikuti rangkaian kegiatan. Pada kegiatan Kupandu Makanmu dan Pembina Selasih, terdapat peningkatan pengetahuan sebesar 80,7\%. Sedangkan, pada kegiatan Tirakato 23 dari 36 anggota keluarga merokok yang mendapatkan pot menyetujui aksi Tirakato.

\section{Saran}

Kegiatan yang dilakukan sebagai upaya penanggulangan hipertensi pada ibu balita perlu dilakukan secara berkelanjutan. Maka dari itu, kegiatan tersebut dapat menjadi usulan kepada pihak pengembangan program Puskesmas Kalitidu untuk dijadikan sebagai kegiatan rutin masyarakat. Hal ini perlu dilakukan untuk mempertahankan dan melihat perubahan perilaku masyarakat akibat perlunya waktu yang tidak sebentar untuk mengubah perilaku seseorang.

\section{DAFTAR PUSTAKA}

Agromedia, Redaksi. 2008. Buku Pintar Tanaman Obat Edisi Pertama. Jakarta: Agromedia Pustaka.

Astawan, Made. 2009. Panduan Karbohidrat Terlengkap. Jakarta: Gramedia Pustaka. 
Buheli, K. L dan Usman, L. 2019. "Faktor Determinan Kepatuhan Diet Penderita Hipertensi." Jambura Health and Sport Journal 1 (1): 20-24.

Desa Kalitidu. 2018. Profil Desa Kalitidu Tahun 2018.

Goni, et al. 2013. "Hubungan Pengetahuan Dan Sikap Ibu Hamil Dengan Status Gizi Selama Kehamilan Di Puskesmas Bahu Kota Manado." Jurnal Keperawatan UNSRAT 1 (1).

Hinkosa, L. T and Negeso, G. 2020. "Risk Factors Associated with Hypertensive Disorders in Pregnancy in Nekemte Referral Hospital, From July 2015 to June 2017 , Ethiopia : Case control study." BMC Pregnancy and Childbirth 20 (16): 1-9. doi: 10.1186/12884-019-2693-9.

Imaroh, I. I . et al. 2018. "Faktor Risiko yang Mempengaruhi Kejadian Hipertensi pada Ibu Hamil di Wilayah Kerja Puskesmas Kedungmundu, Kota Semarang Tahun 2017." Jurnal Kesehatan Masyarakat 6 (1): 570-580.

Junaidi, et al. 2013. Hipertensi Kandas Berkat Herbal. Jakarta: FMedia.

John, A dan Nanji, J. 2005. Senyawa-Senyawa Antihipertensi dan Terapi Obat Hipertensi. Jakarta: EGC.

Khosravi, S, et al. 2014. "Study of the Prevalence of Hypertension and Complications of Hypertensive Disorders in Pregnancy." Open Journal of Preventive Medicine 4 (11): 860-867. doi: 10.4236/ojpm.2014.411097.

Krishnachetty, B. P. F. 2014. "Management of Hypertensive Disorders of Pregnancy". Ananesthesia tutorial of the week 304.

Luo, Z, et al. 2014. "Plasma continine Indicates an Increased risk of preeclampsia in Previos and Passive Smokers".

Malha, et al. 2018. Hypertension in Pregnancy in Hypertension: A Companion to Braunwald's Hearth Disease Third Edition. Elsevier.

Mursito, B. 2002. Ramuan Tradisional untuk Pengobatan Jantung. Jakarta: Penebar Swadaya.

Puskesmas Kalitidu. 2018. Profil Puskesmas Kalitidu Tahun 2018.

Roberts, J. M, et al. 2014. Hypertension in Pregnancy. Washington DC: American College of Obstetricians and Gynecologists.

Taslim, R. W. R. 2016. "Hubungan Pola Makan dan Stres dengan Kejadian di Wilayah Kerja Puskesmas Kamonji." Jurnal Keperawatan 4 (1): 1-8. doi: 10.1504/IJNT.2013.053512. 